\title{
Hungarians in Finland and Sweden: Comparison of Some Sociocultural and Demographic Factors on Language Choice, Culture and Identity
}

BOGLÁRKA STRASZER, Ph.D., University Lecturer, Researcher, Department of Scandinavian Languages, Uppsala university, Sweden

\begin{abstract}
This article provides an overview of some sociocultural and demographic factors of language maintenance and shift among Hungarians in Finland and Sweden, predominately at the group level. Some of the factors described are: the historical background of Hungarian immigration, settlement patterns, demographic development, geographical areas, participation in Hungarian associations along with the attitudes of the majority group towards Hungarians and the Hungarian language. After this some data is presented about language choice, culture and identity of second-generation Hungarians. The article shows that Hungarians are not a single unified group in Sweden or Finland and both groups face factors that can support or hinder the preservation of the Hungarian language and culture. Swedish-Hungarians have a greater ability to preserve their Hungarianism as a group due to population size and concentration in certain areas, while Finnish-Hungarians can maintain their Hungarian identity due to their comparably high status in society and the positive attitudes of the Finnish majority.
\end{abstract}

Keywords: Hungarians in Finland and Sweden, language choice, culture and identity, sociocultural and demographic factors, minority culture, language maintenance and shift, immigrants, second-generation, bilingualism, sociology of language, comparative sociolinguistics

\section{Introduction}

Many sociolinguistic studies carried out on language maintenance and shift focus on language choice and identity among immigrants and their descendants in the Nordic countries. One of the first studies in the Swedish immigrant context is Boyd's survey (see Boyd 1985) which found that children of immigrants often used the minority language only with their parents and older people, and they used the majority language with their siblings and friends their own age. Boyd stated that language shift is ongoing among second-generation youth especially in families where one of the parents speaks Swedish. There are other important studies about language choice and maintenance 
among different groups of immigrants carried out in the Swedish and Finnish contexts, e.g. Olkiewicz 1990; Sirén 1991; Namei 1993; Kosonen 1994; Kostoulas-Makrakis 1995; Janulf 1998; Jasinskaja-Lahti and Liebkind 1999a; 1999b; Kärkkäinen and Mononen 1999; Oinonen 1999 and some data has been collected about immigrants and their descendants in various contexts, presented in Lithman 1987; Boyd, Holmen and Jørgensen 1994a; 1994b; Liebkind 1994. In all of these studies the focus is on the language choice within the family during childhood and there is a clear link between the language use as a young person and language choice and identity later as an adult. The results are often similar to those found in Boyd's survey mentioned above. Some surveys in recent years, for example Österlund-Pötzsch 2003; Otterup 2005; Ågren 2006; Iskanius 2006; Weckström 2008, underline the importance of roots and personal experiences with the parent's language and culture to instill identity in the second-generation. Many of these studies show that the minority language has only a symbolic role in the identity of the second-generation and the majority language is frequently used in every domain.

There is very little information concerning second-generation Hungarians living abroad that investigates their knowledge of Hungarian, their relationship to their own Hungarian roots and the Hungarian language and culture, or patterns of language maintenance and shift, but see Fenyvesi 2005 and later studies in Nordic context as Puskás 2009; György-Ullholm 2010; Kovács 2011. Finland and Sweden are similar in many aspects, however, there are significant differences in how the two countries receive immigrants. It is interesting to compare the language identity of two immigrant groups sharing the same origin but living in two neighbouring Nordic countries. This is why I carried out a comparative sociolinguistic study among second-generation Hungarians. In 2011, I completed my doctoral thesis (see Straszer 2011a) which compares language choice and identity among adults with Hungarian background living in Sweden and Finland. I studied their views on the importance of the Hungarian language and Hungarian cultural heritage for identity. Different factors were reviewed which can affect the language situations among second-generation Hungarians and conclusions were drawn regarding the future prospects of language maintenance and language shift.

My research included a survey which contained multiple-choice questions, open questions, and even space for personal reflections and comments. This survey was completed by 50 Swedish-Hungarian informants and 38 Finnish-Hungarian informants during 2006. The following year I conducted in-depth interviews with 15 of the informants. The informants' answers to the survey were analyzed quantitatively and to some part also qualitatively. The in-depth interviews were analyzed qualitatively and were designed to illustrate differences and similarities at the individual level, showing the language environments of second-generation Hungarians and revealing how varied their situations, language choices and attitudes toward the Hungarian language, culture and background may be. 
In the study I was interested in the linguistic situation of the second-generation and I first studied the informants' backgrounds: how their parents transmitted the Hungarian language and motivated them to use it in their everyday life, what kind of relationship they had during their childhood with Hungary and Hungarian speaking relatives and whether or not they had the possibility to attend classes in their mother tongue at school. I also studied the current situation in their everyday life as adults and their own estimation of their competence in Hungarian and Swedish or Finnish, how often they used the minority language, and the importance of Hungarian culture and traditions in their lives today. Furthermore, I studied their attitudes towards what it means to be "Hungarian" and whether they aimed to maintain their "Hungarian heritage" and pass it on to the next generation. I compared the linguistic situation, sense of identity and attitudes of second-generation Hungarians in Finland and Sweden and tried to pin-point both macro and micro level factors which influence their linguistic situation and affect future prospects for language maintenance or language shift.

This article provides an overview of some factors of language maintenance and shift among Hungarians in Finland and Sweden, at the group level. The historical background of Hungarian immigration, demographic development and geographical areas, settlement patterns, activity in Hungarian associations and public attitudes towards Hungarians and the Hungarian language are described. After the generalizations at the group level the article presents some data about language choice, culture and identity of second-generation Hungarians at the individual level. The data presented is based on the responses to my questionnaire and my report Hungarians, the Hungarian Language and the Hungarian Culture in Sweden and Finland (Straszer 2010a), which includes additional details concerning the factors that lead to language maintenance or shift among Hungarians.

I hope that by comparing persons of the same ethnocultural background who have migrated to different countries we can better understand how immigration policy and sociolinguistic variation in language contact can impact identity.

\section{The historical background}

\section{Hungarians as a brother nation in Finland}

There are only approximately 2000 Hungarians or people with Hungarian roots in Finland. But Hungarians have a long history of contact with Finns and they have a special relationship.

The linguistic affinity between Finnish and Hungarian which was discovered at the end of the $17^{\text {th }}$ century affected the long history of cultural relations between Hungarians and Finns. This phenomenon has played a role in the immigration history of Hungarians in Finland. 
The interaction between Finland and Hungary is believed to have started after some scholarly visits in the beginning of the $19^{\text {th }}$ century which led to an active correspondence between many Finnish and Hungarian scientists, particularly linguists, ethnologists and literary historians and also between members of the Lutheran Church. By the mid-1800s there were frequent scholarly visits between Finland and Hungary. (See more details in Korhonen 1984; Tervonen 1984; Straszer 2009; 2010a; 2011b.)

The Hungarian-Finnish relations became institutionalized in the 1880s when the Finno-Ugric Society was founded in 1883, university level teaching of Hungarian was introduced and a series of Finno-Ugric congresses were launched. In the 1930s, a student exchange program and various kinds of cultural contacts were developed. The so-called Finno-Ugric "heimoaate", the idea of being kindred nations, originates in Finland during the National Awakening. It was at its height from the 1940s until the end of WWII. The Cultural Exchange Agreement, ratified in 1937, contributed to positive Finnish-Hungarian relations. This was the first cultural agreement signed between Finland and a foreign country. This agreement led to an official celebration of the close relationship and affinity between the two peoples and it also gave an official status to the Finno-Ugric cultural congresses. The cultural agreement also contributed to increased opportunities for student exchange, translation of literature, plans for scientific collaboration within Finno-Ugric Studies, and the development of textbooks concerning "the kindred nations" etc. (See more details in Szíj 1989; Varpio \& Szopori Nagy 1990; Straszer 2009; 2010a; 2011b.)

The war years interrupted the lively cultural exchange between the two countries, but despite this, the popularity of Hungarian culture and literature increased in Finland (Varpio \& Szopori Nagy 1990). However, the war provided an opportunity for another type of cooperation between Hungarians and Finns, namely a military cooperation. By March 1940, 25,000 Hungarian men had volunteered for front duty and wanted to help when Finland was in need. And the gratitude of the Finns translated into an even stronger romanticizing of the Finno-Ugric affinity. (See more about it in Richly 1996 ; Straszer 2009; 2010a; 2011b.)

During the post-war years, the practical cooperation between Hungarians and Finns can be observed in various fields, especially through the foundation of the FinnishHungarian Society in 1950 and the strengthening of the Cultural Exchange Agreement in 1959. The first so-called Hungarian-Finnish Friendship Week was organized in 1967, and its sponsors were the leading statesmen of the two countries. Many other agreements were also signed between the two countries (see more details in Nagy 1984: 14). These agreements can be regarded as expressions of mutual trust between the countries despite different social orders. In those days, Hungary's connections to Western countries were generally restricted and therefore the relations with Finland were a great exception. Even the Finno-Ugric language affinity had offered political advantages to Hungarians for many years. (Straszer 2010a; 2011b.) 
Hungarian immigration to Finland never had the character of group immigration, rather, it can be seen as a series of individuals moving to Finland independently. Because Finland did not accept refugees in the 1950s and 1960s, very few Hungarians came to Finland during that period even though there were difficulties in Hungary. Prior to the late 1960s the Hungarian immigration was rather sporadic and most of the people came for familial reasons, by special invitation for work or through cultural or church contact. Those Hungarians who did come in the 1970s and 1980s usually came through personal contacts or to work for economic reasons. And in the late 1980s and early 1990s, some Hungarian refugees from Romania were admitted, too. Hungarians in Finland became associated with professions such as music teaching as well as other highly specialized fields, such as, within medical and technical industries. Since the 1990s, more and more Hungarians have come to Finland as guest-workers or exchange students, but remain only for a limited time. (Straszer 2009; 2010a.)

Finally the cultural relations between Finland and Hungary are an example of the close feeling of togetherness between Hungarians and Finns. The feeling of affinity between Finno-Ugric peoples has led to an unforeseen solidarity between Finland and Hungary and this historical heritage still seems to positively affect the status of Hungarians and the Hungarian language in Finnish society. Hungarian immigrants in Finland are considered members of a brother nation. (See more details about it in Straszer 2011b.)

\section{Hungarians as refugees in Sweden}

There are around 25,000-35,000 Hungarians or people with Hungarian roots in Sweden.

Hungarians have a long history of contact with Sweden. According to Svanberg \& Tydén (1992: 104), Hungarians have been found on Swedish soil as early as the time of King Gustav Vasa and since the Hungarian revolution and struggle for independence between 1848 and 1849 . In the $19^{\text {th }}$ century, there were, however, only some twenty Hungarians recorded in Sweden, while by the end of the First World War there were roughly one hundred (Szabó 1988: 463-464).

Hungarians became visible in Swedish society after the First World War when Hungarian communists, exiled Social Democrats, high-level officials and a hundred evacuated children were received among the other refugees taken in by Sweden. During the inter-war years, many academics, authors, artists, musicians and politicians came to the country. The first organized immigration was a group of Hungarian Jews who were rescued from German labor and concentration camps as a result of the 1945 Bernadotte-offensive. However, some of them died shortly thereafter or continued their emigration to third countries. At the turn of 1947, still more Hungarians arrived to Sweden. This time it was due to an organized influx of foreign labor from the northern and northeastern parts of Hungary, including approximately 400 Hungarian 
agricultural laborers and 100 forestry workers and their immediate family members. These Hungarians came to Sweden on a two-year contract, but after the communists took power in Hungary in 1948, most families refused to go back. They were either granted political asylum or they emigrated again to third countries. (Szabó 1988, 464; Svanberg \& Tydén 1992, 255-256, 328, 397. See more in Straszer 2010a.)

The most extensive immigration of Hungarians to Sweden occurred during and after the Hungarian uprising in the autumn of 1956 and the winter of 1957. Sweden was one of the first countries to receive Hungarians, a decision made the day after the Soviet invasion. From 1956 to 1958, Sweden received approximately 8000 Hungarians, which was, at the time, the largest number of immigrants from a single country to come to Sweden since the Second World War. Sweden also received Hungarian refugees who were suffering from tuberculosis (TB) and their family members; altogether there were 1000 refugees. Thanks to Hungarian immigration, Sweden received a valuable contribution to its labor-force, since those arriving consisted mainly of young people with a high level of education. Roughly $60 \%$ of these Hungarian immigrants were under 25 years old, many were students, and the men outnumbered the women. There was also a great number of metal workers, engineers, technicians, textile workers, agricultural laborers, construction workers, office workers and doctors. Car mechanics, chauffeurs, masons, relief workers, laborers, assistant nurses, nurses, waitresses and teachers were also well represented. (Svensson 1992, 13, 142, 153-154; Szabó 1988, 464.)

Hungarians continued to immigrate to Sweden at a steady rate, though on a lesser scale until the end of the 1980's. On average, approximately 300 persons arrived annually during those years, and, according to Statistics Sweden, it is estimated that in all 15000 Hungarians immigrated to Sweden, a figure which includes those refugees that came during the 1980s to escape political persecution. The latter contained a high concentration of Hungarians who came from outside the present borders of Hungary, mostly from Romania, Slovakia and the former Yugoslavia. Immigration from Hungary to Sweden during the second half of the 1990s amounted to approximately 165 persons annually, rising to 200 individuals during the early 2000s. (SCB 1987, 75; 2006, 310; Straszer 2010a.)

Hungarian immigration in the 2000s consists of individuals and families often looking for temporary work. When the European Union extended membership to Hungary and other Eastern European states in the spring of 2004, the Swedish government feared a wave of "social tourism" from these new member states, but this so-called Eastern European migration never occurred (see Zsiga 2007, 47-52). In 2008, a shortage of labor led many Swedish municipalities to recruit labor from Hungary, for example, Småland needed workers in the iron and metalworking industries and Södermanland needed medical doctors (Straszer 2010a). 


\section{Demographic development and geographical areas}

\section{Immigrant group with little concentration in Finland}

Hungarians account for a rather small immigrant group in Finland. Statistics about the number of Hungarians who moved in and out of Finland during the time prior to the 1970s are not accurate and the only numbers to go by are the number of Hungarians living in Finland prior to the 1980s. According to Leitzinger (2008, 59-121), there were less than 150 Hungarians in Finland prior to the 1980s, and this number included Hungarian speakers, Hungarian citizens and persons born in Hungary. A steady increase of the number of Hungarians began in the 1990s and with a more noticeable increase during the early years of the $21^{\text {st }}$ century. (Straszer 2009.)

According to Finnish statistics, in 2011 there were 2181 people who have Hungarian as their mother tongue, 1536 who hold Hungarian citizenship and 1776 who were born in Hungary (source: FSBS 2012). (See table 1.) These statistics reveal that the number of Hungarian speakers in Finland outnumbers those who were born in Hungary or hold Hungarian citizenship. The reason for this is that Hungarian speakers include those who have arrived from the Hungarian areas of Slovakia, Ukraine, Rumania or former Yugoslavia, as well as those Hungarians who had earlier changed their citizenship from Hungarian to Finnish and children born in inter-ethnic families. The statistics do not account for those persons who hold dual citizenship in Finland and Hungary as they are only included in the statistics over Finnish citizens. (Straszer 2009.)

Table 1. Regional distribution for the year 2011 of persons born in Hungary, persons holding Hungarian citizenship and persons who have Hungarian as their mother tongue in descending order according to county.

\begin{tabular}{l|c|c|c}
\multicolumn{1}{c|}{ Year 2011 } & Born in Hungary & $\begin{array}{c}\text { Citizenship } \\
\text { Hungarian }\end{array}$ & $\begin{array}{c}\text { Hungarian as } \\
\text { mother tongue }\end{array}$ \\
\hline \multicolumn{1}{c|}{ AlI } & $\mathbf{1 7 7 6}$ & $\mathbf{1 5 3 6}$ & $\mathbf{2 1 8 1}$ \\
\hline Uusimaa (I and II) & 727 & 594 & 957 \\
\hline North Ostrobothnia (XVII) & 175 & 174 & 195 \\
\hline South Ostrobothnia (XIV) & 172 & 170 & 194 \\
\hline Pirkanmaa (VI) & 138 & 121 & 178 \\
\hline Ostrobothnia (XV) & 122 & 115 & 131 \\
\hline Varsinais-Suomi (III) & 81 & 68 & 125 \\
\hline Central Finland (XIII) & 49 & 45 & 63 \\
\hline Kanta-Häme (V) & 50 & 48 & 61 \\
\hline Satakunta (IV) & 42 & 26 & 42 \\
\hline Päijät-Häme (VII) & 40 & 26 & 41 \\
\hline South Karelia (IX) & 31 & 23 & 31 \\
\hline Kymenlaakso (VIII) & 26 & 25 & 30 \\
\hline Pohjois-Savo (XI) & 30 & 26 & 29 \\
\hline Lapland (XIX) & 23 & 21 & 26 \\
\hline North Karelia (XII) & 22 & 19 & 23 \\
\hline Central Ostrobothnia (XVI) & 22 & 20 & 22 \\
\hline Etelä-Savo (X) & 12 & 8 & 16 \\
\hline Aland (XX) & 7 & 1 & 10 \\
\hline Kainuu (XVIII) & 7 & 6 & 7 \\
\hline
\end{tabular}

(๑) This map has been provided for my study by Anneli Hänninen at the Institute for the Languages in Finland. 2010.

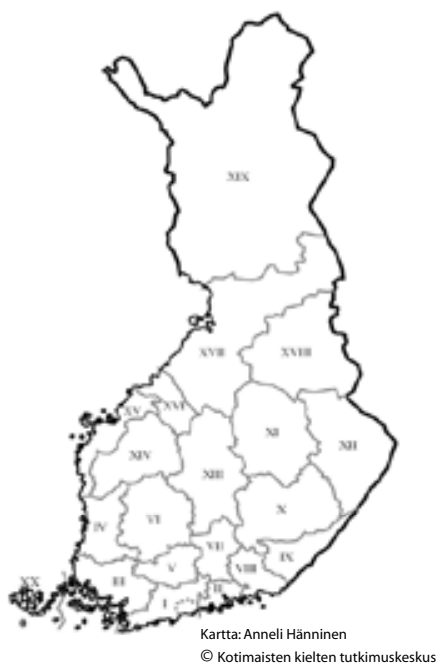

(c) Kotimaisten kielten tutkimuskeskus 
The largest group of Hungarians lives in the area surrounding the capital, but the Hungarian population is spread across the entire country. According to the statistics (see above), $40 \%$ of the Hungarian immigrant population live in Uusimaa. Just under half of the Hungarians are women and approximately $40 \%$ of those born in Hungary are between the ages of 30 and 40 years old. (See more details about Hungarians in Finland in Straszer 2009; 2010a; 2010b; 2011b.)

\section{Immigrant group with a slightly larger concentration in Sweden}

Immigrants in Sweden are registered simply according to their citizenship and country of birth, which means that Hungarian-speakers from the regions surrounding Hungary, who ethnically and linguistically identify themselves as Hungarians, are excluded from the statistics (thus Table 2 presents only a portion of the Hungarian population in comparison to Table 1). Also excluded are those Hungarians who have changed their citizenship as well as the majority of second- and third-generation Hungarians. Hence it is impossible to determine the number of Hungarians in Sweden, it is only possible to make an estimation with the help of the data available. Mátyás Szabó, a SwedishHungarian who has investigated change of citizenship among Hungarians, estimates that in 1995 there were roughly 27000 Hungarians in the country, the majority of whom were already naturalized (see Szabó 1997, 199). However, in other sources (e.g. Szöllösi 1999, 68) the number of Swedish-Hungarians can run up to 30000 , and in some Hungarian documents (e.g. HTMH 2006) as many as 35000 (cf. MV 1996,14-15; Kovács 1999, 49; Borbándi 1996, 118).

The number of Swedish-Hungarians in 2009 according to data from Statistics Sweden is presented in Table 2 (SCB 2010). Table 2 shows persons born in Hungary, 15 119, according to regional distribution in Sweden for the year 2009. The table shows that, more than half of those born in Hungary, 73\%, live in one of three counties: Skåne, Stockholm and Västra Götaland while in the other counties there are relatively few Hungarians. (See also Straszer 2006a; 2006b; 2010a; 2011c.)

Because of political and economical instability in Hungary immigration from Hungary in recent years amounts to approximately 800-900 persons per year, while another 100 persons become naturalized in Sweden. In 2009 there were 6100 second-generation Hungarians, or persons born in Sweden with two Hungarian-born parents. Of these second-generation Hungarians, 3196 are men and 2904 are women (see SCB 2010 and for additional details about Hungarians in Sweden see Straszer 2010a; 2011c).

It can be concluded that Hungarians in Finland and Sweden form a heterogeneous group, not only in terms of their reasons for and time of immigration, but also in their areas of residence and in terms of their culture. Even their religious convictions and educational backgrounds differ (see additional details in Straszer 2010a and 2011a). 
Table 2. Regional distribution for the year 2009 of persons born in Hungary in descending order according to county.

\begin{tabular}{l|c}
\multicolumn{2}{c}{ Year 2009 } \\
\hline \multicolumn{1}{c}{ Coll } & Born in Hungary \\
\hline \multicolumn{1}{c}{ Corty of registration } & $\mathbf{1 5 1 1 9}$ \\
\hline Skåne (12) & 4269 \\
\hline Stockholm (01) & 4064 \\
\hline Västra Götaland (14) & 2736 \\
\hline Kronoberg (07) & 517 \\
\hline Södermanland (04) & 470 \\
\hline Jönköping (06) & 438 \\
\hline Osstergötland (05) & 383 \\
\hline Halland (13) & 372 \\
\hline Västmanland (19) & 343 \\
\hline Uppsala (03) & 327 \\
\hline Örebro (18) & 219 \\
\hline Värmland (17) & 187 \\
\hline Gävleborg (21) & 155 \\
\hline Kalmar (08) & 154 \\
\hline Blekinge (10) & 153 \\
\hline Dalarna (20) & 139 \\
\hline Västernorrland (22) & 64 \\
\hline Västerbotten (24) & 44 \\
\hline Norrbotten (25) & 34 \\
\hline Jämtland (23) & 32 \\
\hline Gotland (09) & 19 \\
\hline
\end{tabular}

(C) This map has been provided for my study by Muriel Bjureberg at the Swedish mapping, cadastral and land registration authority, Lantmäteriet. 2011.



\section{Institutions and organisations by Hungarians}

\section{Active individuals in Finland}

As a group, Hungarians in Finland do not participate in activities at Hungarian societies to the same extent as the Swedish-Hungarians (see below). In Finland, there are only a few Hungarian associations, for example the Finnországi Magyarok Egyesülete, FME [Association of Hungarians in Finland] which has about 100 member families around the country. The FME was established in 1993, but received its official status first in 1997 and since then has worked actively to preserve the Hungarian language, culture and customs, celebrate some Hungarian commemoration days and support new Hungarian immigrants.

Other vital organizations include the ecumenical Hungarian Congregation Group, Finnországi Magyar Gyülekezet, FMGY, established at the end of the 1990's and two Hungarian Children's Clubs, the "Bóbita" established in 1998 and the "Ovi Klub" which was established in 2005. These organizations have previously been most active in Helsinki and its surroundings, but in the past years the teaching of Hungarian to children has expanded to other larger cities such as Turku and Tampere as well. In 
these cities Hungarians have also organized folk dance evenings with the form as the old traditionally "táncház" along with other activities.

Hungarians in Finland are more active as individuals. They often have self organized groups or activities within their own family and with both Finnish and Hungarian friends. They can all use the services of the Hungarian Cultural and Scientific Centre, which is maintained by the Ministry of National Resources and the Finnish-Hungarian Society and found throughout Finland. The Finnish-Hungarian Society is one of the biggest friendship societies in Finland. It was established in 1950 by Finnish people who were interested in Hungary, Hungarian culture, people and language. Today it has over 50 local societies with a total of 4300 members, though the families and neighbors of the members may also participate in the activities. The Finnish-Hungarian Society organizes a Hungarian theme week in Finnish schools every fourth year. 4000 schools get an informational magazine about Hungary and the Hungarian language and culture and many municipalities, especially the 51 municipalities which have a Friendship Town in Hungary, have events in almost every school during theme week. The Finnish-Hungarian Society organizes other big events too, for example, the "Sunday walk to Hungary" -event, which most recently had 1000 visitors and the Finnish-Hungarian Friendship Town Weeks in which several hundred people are involved. Every local society has programs and various activities throughout the year, for example: concerts, seminars, drawing for children, exhibitions, dance evenings, music and theater trips, theme trips to Hungary, language teaching, library events, book publishing, student and teacher exchange, culinary events, wine courses, craft shows and bazaars with relevance to Hungary and Hungarian culture. ${ }^{1}$

There is a strong co-operation between many of these organizations and the Embassy of Hungary and it is important to remember that many Hungarians are well-known in Finnish society because of their excellent work in various fields. (See Nagy et al. 1984; Gerevich-Kopteff 1993; Straszer 2009; 2010a; 2011b.)

\section{Active groups in Sweden}

In Sweden, Hungarians are active as a group and have several associations and organizations, which work actively around the country. The first Hungarian associations were founded in connection with the organized immigration of the Hungarians in 1957 (Svensson 1992, 176, 226). In the 1960s there were already roughly 60 active Hungarian associations throughout Sweden, including religious congregations, sports clubs and song and dance groups (Szabó 1988, 466). The most active associations were located around big cities, i.e. in Stockholm, Gothenburg and Malmö, and in industrial centers such as Västerås, Södertälje and Olofström. A national committee was established in 1974 which was the precursor to Svédországi Magyarok Országos Szövetsége (SMOSZ) [The Swedish Federation of Hungarians], which was founded in 1976 and is still active today. This national

\footnotetext{
${ }^{1}$ The data is based on personal correspondence with Marjatta Manni-Hämäläinen, the executive director of the Finnish-Hungarian Society, September 2012.
} 
federation is for civil associations of Swedish-Hungarians and it is politically independent. Its objectives are to facilitate Hungarians in their integration into Swedish society, preserve the Hungarian language, culture and customs, maintain good relations between Hungary and Sweden and support and encourage the activity of the local associations (SMOSZ 2008). The Swedish Federation of Hungarians has grown steadily and today it has 39 local associations in 18 towns all over Sweden and has more than 5000 paying members (see SMOSZ 2008). There are also some special cultural associations and aid organizations. (HTMH 2006; SMOSZ 2008. See also Straszer 2006b; 2010a, 59-64.)

The SMOSZ has two headquarters and one Hungarian parish building in Tångagärde, in the municipality of Ulricehamn, where many scout camps, language and translation camps, meetings and festivities have taken place over the course of several decades. The Hungarian organizations arrange approximately $1200-1300$ events each year (sic), for which they receive support from the Swedish state. (See among others HTMH 2006; SMOSZ 2008; Straszer 2010a.)

The church also plays an important role for many Swedish-Hungarians, not only because of its regular church services, but also because it provides support and an opportunity to socialize with other Hungarians (Szabó 1988, 468). Taking part in church services and in Christian holy days provides an opportunity for many Hungarians to meet other Hungarians and to belong to a community characterized by a common language. ${ }^{2}$

The latest addition to the Hungarian organizations and associations is a Hungarian choir, which was founded in Stockholm in 2007. One of the choir's most important tasks is to preserve the Hungarian culture and language through music. The choir collaborates with several other Hungarian organizations in the country. Last but not least, there is the Swedish-Hungarian institute, the Északi Magyar Archívum [The Hungarian Archive]. The archive was founded in 1973 and is maintained by a private person in Stockholm (Straszer 2010a).

Concerning Swedish-Hungarians' activity in the associations it has been noted that some Hungarians distinguish between Hungarians who have come from Hungary and those who are from neighbouring countries. Szabó $(1988,466)$ is not alone in noticing that Hungarians coming from Romania have distinct ideas regarding their cultural identity. This has been attributed to the fact that this group is the most active in the associations. For many Swedish-Hungarians, activity in the associations constitutes a natural part of their lives. This is especially true for the first generation and newcomers, while second- and third-generation Hungarians participate less. ${ }^{3}$

\footnotetext{
${ }^{2}$ The information is based on a recorded interview with the Hungarian priest Pál Molnár-Veress 26 April 2007.

${ }^{3}$ The claim was also emphasized by the Hungarian priest Pál Molnár-Veress in the interview on 26 April 2007.
} 


\section{Public attitudes}

\section{Hungarians with high status in Finland}

Since the 1980s, some studies have been conducted on attitudes toward immigrants, immigrant languages and immigrant cultures in Finland. The most comprehensive of them was carried out 2003 by Magdalena Jaakkola (2005), but attitudes towards Hungarians were not included in the study. Hungarians have not been included in other attitude studies either. Jaakkola estimates that the attitudes towards Hungarians as a kindred nation may be more positive than the attitudes towards many other nationalities. She also refers to the fact that Finns have a very positive attitude towards speakers of other linguistically related languages, such as Ingrian Finns (Russian Federation) and Estonians. ${ }^{4}$ Yet, positive attitudes towards Ingrian Finns and Estonians may also be caused by other factors, such as geographical proximity and a shared history (cf. Lepola 2000, 366). However, the fact that Hungarians immigrated as professionals or through marriage, can also have had a positive influence on the situation of the Hungarians. (See discussions in Straszer 2009; 2010b.)

Travelling to Hungary and studying the Hungarian language and culture is quite popular hobby among Finns. The Finnish-Hungarian Society has a significant role in this, too. There are no general statistics about how many people have studied Hungarian in Finland, but it is possible to study Hungarian at several Finnish universities as well as in over 30 municipalities in workers' colleges, open colleges or colleges organized by the local societies of the Finnish-Hungarian Society etc. Some teaching materials and books which the Finnish-Hungarian Society have produced are very popular; they have sold 3000 teaching books and 5500 conversation books in Hungarian and their teaching program is shown by the Finnish Broadcasting Company in reprise. ${ }^{5}$ In addition to this, it is noteworthy that since 1998 Hungarian is an optional subject in some secondary schools. Furthermore, all those who study Finnish in Finland at the university level and those who study to become teachers of Finnish study Hungarian. Finnish primary school pupils learn about the kinship between the Finno-Ugric languages during their mother tongue lessons. Futhermore in Finland, Hungary is often visible in the press and books dealing with the Hungarian language and culture are frequently published particularly by the Finnish Literature Society. Book translations from Hungarian to Finnish are also regularly done and during the year 2012 Hungary and the Hungarian literature have been a special theme at the Helsinki Book Fair.

The Cultural Exchange Agreement is an important factor in raising the status of the Hungarian language and culture in Finland. The shared history has a primary role in the relationship between Hungarians and Finns. As mentioned above the feeling of affinity between Finno-Ugric peoples led to a special solidarity and good relationship


also Jaakkola 2000 and 2005.

${ }^{5}$ The data is based on personal correspondence with Marjatta Manni-Hämäläinen, the executive director of the Finnish-Hungarian Society, September 2012.
} 
between Finland and Hungary. The situation of Hungarians in Finland is different than other immigrant groups and languages because Hungarian was part of the Finnish nationalist/modernist language emancipation. The unique nature of the relationship between Finns and Hungarians has been said to originate from the so-called folk diplomacy (in Hungarian népi diplomácia). This term denotes the contact that is not derived from official, diplomatic relationships between states, but rather is based on grass roots activities such as active friendship town networks between Finland and Hungary, cooperation between choirs, schools, congregations, sports clubs, societies and various hobby circles, as well as other activities which the political elite of Finland and top-level officials often contribute to. ${ }^{6}$ The wide spread study of Hungarian in Finland is a further indication of the high prestige that Hungarian enjoys and the positive attitudes towards it among Finns in general. Both official support from the state level and the favorable attitudes among majority language speakers contribute to the privileged status of Hungarians among immigrant groups in Finland.

Positive attitudes on the part of the Finnish people are also manifested by ample anecdotal evidence from Hungarian authors (e.g. Kodolányi 1939) and also by other Hungarians who have visited Finland or lived there (e.g. Abonyi-Karhunen 2005). (See more various details and examples in Straszer 2009; 2010a; 2010b; 2011b.)

Finally it can be established that the Finno-Ugric linguistic affinity has evoked a long history of cultural and political relations between Hungarians and Finns and this culture historical heritage still seems to positively affect the status of Hungarians; whether as tourists or immigrants, Hungarians are considered members of a brother nation. We have only limited scientific data about the public attitudes toward Hungarians, but we have many other proofs, such as the fact that thousands of Finns are involved in activities with Hungarians and their language and culture (for example through the Finnish-Hungarian Society), which shows that the general attitude towards the Hungarian language and culture as well as Hungarians is exceptionally good in Finland.

\section{Hungarians with low status in Sweden}

In Sweden there have been several studies regarding the ways in which Swedes regard immigrants, but none of them clearly maps out the opinions of the majority population towards Hungarians (Straszer 2010a, 52). Regarding Swedish attitudes towards Hungarians there is very little information. There are two studies that included Hungarians in the target group: Lundquist \& Busch (1966) and Svensson (1992). These works looked at Swedish attitudes regarding the wave of immigration of Hungarian refugees and their attitudes towards Hungarians following the Hungarian Uprising of 1956. In describing the situation of those Hungarians who arrived in Sweden during the second half of the

\footnotetext{
${ }^{6}$ The data is based on personal communication with the former leader of the Hungarian Cultural and Science Centre, Árpád Jelinkó, who nowadays functions as the Hungarian attaché of Sciences and Culture and on personal correspondence with Marjatta Manni-Hämäläinen, the executive director of the Finnish-Hungarian Society, January 2008. See also Nagy et al. 1984; Honka-Hallila 2000.
} 
1950s, Svensson found that the Swedish labor market played a key role in determining which refugees were selected and granted entrance into Sweden (1992, 24-25). The reception of Hungarian refugees can thus be classified as a humanitarian-based recruitment of workers. This could explain why Hungarian refugees were enthusiastically welcomed into Sweden (see Kós-Dienes 1986; Lundquist \& Busch 1966; Svensson 1992). The fact that the Swedish people received the Hungarians positively may have other causes as well. For example, the sympathy that the Swedes had for the Hungarians was described in 1957 by Nils Erik Bæhrendtz with the following words: "The desire to help has been and is still important for the Swedish people, the universal opinion in Sweden has been a rarely seen solidarity and sympathy for the struggling Hungary." (Bæhrendtz 1957, 7; see also Lundquist \& Busch 1966, 138-139).

According to Svensson $(1992,228)$, Hungarians constituted a more privileged group in many ways compared to other refugee and immigrant groups in Sweden. The Swedes had a general goodwill and obliging attitude towards the Hungarians, though at the same time they had a limited knowledge of foreigners (Svensson 1992, 150). The Hungarians that came to Sweden in the end of the 1940s and even those arriving in 1956-1957 were perceived as adding a "picturesque feature" to Swedish society (Svensson 1992, 150. See also Straszer 2006a). The attitudes of the Swedish towards the Hungarian refugees were positive, both at the national level and among the general public; there was a clear interest in the Hungarians (e.g. Svensson 1992, 186, 233). However, this positivity changed during the spring of 1957 when there was negative publicity following the inappropriate actions of some Hungarians which resulted in Hungarians being met with a more diminished sense of sympathy than they had encountered upon their arrival (Svensson 1992, 178-186, 233-234).

Apart from the aforementioned studies reporting on opinions regarding immigration there have been studies on attitudes towards other languages which even included attitudes towards immigrant languages. One study which was done on attitudes towards other languages was reported in SOU 2002:27. This study reveals that the support for maintaining immigrant languages in Sweden is less than the support for maintaining minority languages; however, a majority of the population are positive towards multilingualism (SOU 2002, 198, see also Nygård 2002). In Wingstedt (1998), similar attitudes are described. These reports, however, do not refer to attitudes towards the Hungarian language specifically. Some information regarding Swedish attitudes specifically towards the Hungarian language can be found in a smaller research project, a Bachelor's thesis, written by Hellman (2004). This study revealed that the attitudes of the majority population towards a language are directly affected by the general view of the country where the immigrants originate. Swedes are, according to Hellman $(2004,46,48)$, particularly interested in learning immigrant languages which are seen as high prestige languages and are associated with prosperous countries and cultures. However, Swedes show less interest in immigrant languages spoken in poor or war- 
torn countries. Hellman's results showed that Hungarian did not raise interest among those who answered her survey concerning immigrant languages.

In summary, Hungarians in Sweden represent a relatively unknown and unseen group and the Hungarian language and culture do not raise interest among the majority population. The fact that Hungarians have quickly established themselves in the Swedish labor market and become well-integrated and equal members of the Swedish society has possibly affected the way in which they are viewed. Since the number of Hungarian immigrants is relatively small compared to other immigrant minority groups in Sweden today, Hungarians are rarely mentioned in studies which attempt to identify Swedish attitudes toward different minority groups today which has resulted in a very limited understanding of how the majority population view Hungarians as a group in contemporary society. Interestingly though this argument can not apply to Hungarians in Finland.

\section{Language choice, culture and identity}

In the study conducted for my doctoral thesis there were 88 informants. Among the 50 Swedish-Hungarian informants, there were 27 women and 23 men and in the Finnish-Hungarian group of 38 informants there were 15 women and 23 men. In the Swedish-Hungarian group more than half of the informants were under the age of 35 ( 10 were between the ages of 18 and 25 and 17 were between 26 and 35), while 14 informants were between the age of 36 and 45 and nine informants were over 45 . The Finnish-Hungarian group was a little bit younger, because most of them were under the age of 35 (nine were between 18 and 25 and 20 between 26 and 35), while seven informants were between the age of 36 and 45 and only two informants were older than 45. More than half of the informants in both countries, 28 Swedish-Hungarians and 20 Finnish-Hungarians, were highly educated, i.e. they have studied at university and/or have university degree. Only 4 Swedish-Hungarian informants were born in Hungary and the rest were born in Sweden. 33 informants had lived their entire life in Sweden, while 7 informants had also lived or spent a shorter period of time in Hungary. But 12 of the Finnish-Hungarians were born in Hungary and 26 in Finland and 20 informants had lived their entire life in Finland, while as many as 15 informants had also lived or spent a shorter period of time in Hungary. Most of the Swedish-Hungarian informants (43) had sole Swedish citizenship; the remainder (only seven) had dual or triple citizenship. But among the Finnish-Hungarians 22 had sole Finnish and one had sole Hungarian citizenship; the remainder (15) had dual Finnish and Hungarian citizenship. Almost all informants (45) in Sweden and more than half of the Finnish-Hungarians (23) had a Hungarian association near their current area of residence.

Of the 50 Swedish-Hungarian informants more than half (29) came from families where both parents were Hungarian speaking. However, four informants had a Hungarian speaking mother and a Swedish speaking father and three had a Hungarian speaking 
mother and a father whose mother tongue was neither Swedish nor Hungarian. 14 of the informants had a Swedish speaking mother and a Hungarian speaking father. Of the 38 Finnish-Hungarian informants only nine came from families where both parents were Hungarian speaking. Most of the informants (21) had a Hungarian speaking mother and a Finnish speaking father and seven informants had a Finnish speaking mother and a Hungarian speaking father. ${ }^{7}$ Only one informant in the Finnish-Hungarian group had a Hungarian speaking father and a mother whose mother tongue was neither Swedish nor Hungarian. In the Swedish-Hungarian group the majority of Hungarian fathers (31 of 43) had come to Sweden from Hungary as refugees in 1956-57 and only three had moved for family reasons. Half of the Hungarian mothers (18 of 36) had come to Sweden from Hungary as refugees, 12 for family reasons and two came for work. In the Finnish-Hungarian group the situation was different; the majority of Hungarian mothers (19 of 30) moved to Finland from Hungary for family reasons and the remainder came for work or study and there were no female refugees. Most of the Hungarian fathers (13 of 17) moved to Finland for work, three came for family reasons and only one was a refugee. The majority of parents in the both groups were highly educated. However, there were also some who had only completed compulsory school. The mothers had a slightly lower level of education than the fathers. Among the parents in Sweden there were, for example, doctors, teachers, engineers, agronomists and economists and some parents had already retired. The parents in the Finnish group were special, because one-third of them were musicians and music teachers and many of the other parents were engineers, entrepreneurs and researchers. A large percentage (41 parents in Sweden and 31 parents in Finland) were members or active members of some Hungarian associations.

The main differences between the Finnish-Hungarian and Swedish-Hungarian informant groups can be summarized in the following way: the Swedish-Hungarian group is bigger and there are more women who take part in the study. They are on average older than Finnish-Hungarians and have a slightly higher education. More Finnish-Hungarian informants were born in Hungary and many more have retained dual citizenship than in the Swedish-Hungarian group. More Swedish-Hungarians have a Hungarian association near their area of residence and the Swedish-Hungarian parents have been more active in them. Most of the Swedish-Hungarians come from families where both parents are Hungarian and most of the Finnish-Hungarian informants come from intermarried families, most of them having a Hungarian mother and a Finnish father. The SwedishHungarian parents have a lower education than the Finnish-Hungarian parents as well as different reasons for immigrating.

In the survey several research questions were raised. The first question examined in which domains the Hungarian language is primarily used by second-generation Hungarians among the two groups. First the informants estimated their proficiency in Hungarian and

\footnotetext{
${ }^{7}$ One informant came from a family where the Finnish speaking father also has Swedish as his mother tongue.
} 
their proficiency in the majority language, Swedish or Finnish. The Swedish-Hungarian informants compared their language proficiency in Hungarian to proficiency in Swedish in the following way: 5 of 50 said that they know Hungarian equally well, while the majority 37 of 50 said that they know Hungarian a little less or much less than Swedish. Six informants had no knowledge of Hungarian at all. It is interesting that not one of the informants claimed to know Hungarian either slightly better or a lot better than Swedish. The Finnish-Hungarian informants' estimation was little bit more positive, because they compared their language proficiency in Hungarian to proficiency in Finnish in the following way: little more than half, 24 of 38, know Hungarian a little less or much less than Finnish, but as many as 11 of 38 know Hungarian equally well. There was one person who estimated that she knows Hungarian much better than Finnish. The research shows that the majority language, either Swedish or Finnish, is more active both in the home and outside of the home of second-generation Hungarians than the Hungarian language. Outside the home the informants used Hungarian mostly in family-related domains, and primarily with their relatives and, in many cases, only while in Hungary. The language choice of the informants inside the home was dependent on their own background and upbringing, but it was more likely to be determined by their current life situation and more specifically the language(s) their partner had and which language they chose to speak with each other. Language choice outside of the home was also based on other factors, for example language ability.

The second research question dealt with the relationship between the informants' language choices and their language environment during childhood. There was no single pattern between the various informants' childhood exposure to the mother tongue. The parents did not exclusively use their own mother tongue when speaking with each other or with the children, instead the study revealed several different patterns of communication between the informants and their parents. Roughly one-fourth of the Swedish-Hungarian informants' mothers used Hungarian exclusively when talking to the informants and the same number predominantly used Hungarian but also used Swedish to some extent. One-third of the fathers exclusively used Hungarian and almost half exclusively used the majority language. In the Finnish-Hungarian group more than half of the mothers used Hungarian exclusively when talking to the informants and only in a few families did the mothers use both Hungarian and Finnish. Fathers' language choice in Finland is quite similar to fathers in Sweden. Furthermore, the Hungarian speaking parent, especially the mother, frequently code-switched and to some extent used Swedish or Finnish when communicating in the family. It is also interesting that in some families the parents used different languages with different children in the family. One-third of the Swedish-Hungarian informants only used Hungarian at home as a child while onethird only used Swedish or a third language. Among the remaining third, the extent to which both Hungarian and Swedish were used at home varied. In the Finnish-Hungarian group half used only Hungarian at home with their parents and siblings and one quarter 
never used the minority language. The remainder communicated in the family both in Hungarian and Swedish and in some home the parents used other languages, such as English or German, when speaking with each other.

There are some differences in language choice between informants whose parents were both Hungarian versus those who had one Hungarian parent. In general those informants coming from homes where both parents spoke Hungarian have a better knowledge of Hungarian than those who had only one parent who spoke Hungarian. However, those who had only one Hungarian parent, read books, listened to music and radio and wrote e-mails and letters in Hungarian more often than informants with two Hungarian parents. Informants who had both parents who were Hungarian speak Hungarian more actively than other informants, mostly on the telephone with relatives and they meet other Hungarians more often, too. It is also worth mentioning that informants with two Hungarian parents visited Hungary as children more often than the other informants, but informants with only one Hungarian parent visit Hungary more frequently as adults than informants with two Hungarian parents. Also informants with one Hungarian parent follow news about Hungary to a greater extent and -have a more positive relationship to the Hungarian language and their Hungarian roots.

The research shows that the most active users of Hungarian come from families where the language was actively used during childhood and where the visits to Hungary were regular. It was apparent that the informants' attitudes and stances on language maintenance were affected by their parents' use of the language, contact with the homeland, contact with other Hungarian speakers and attitudes toward the Hungarian background and language. The language environment while growing up still has an important impact on the language choice of second-generation Hungarians, but due to the limited sample in this research it is not possible to determine the degree of impact that the various factors have. However, some factors, such as, parents' education, participation in Hungarian circles, routine visits to Hungary and the informants' participation in mother tongue education, do have a positive effect on the informants' ability to use Hungarian and thereby affect their language choice both when they were children and today. The research also shows that a balanced bilingualism exists among those informants whose parents consistently used Hungarian when communicating with them as children.

The third research question was regarding the informants' views concerning the importance of the Hungarian language and cultural heritage for identity. A majority of the informants were positive and stated that knowledge of the language is important for people with Hungarian background. Most of the informants replied that the Hungarian background is meaningful because it makes up a part of their identity. For most of them, the Hungarian background reminds them of their heritage, roots, family history and it gives them access to another culture, another language and another country. The Hungarian background is most often seen as a treasure offering diversity in life. The 
informants' identity and positive attitudes to their Hungarian background were mostly affected by their experiences and social networks during childhood, by their visits to Hungary, the use of Hungarian in the home, participation in mother tongue education and the family's involvement in Hungarian circles. These positive results may be due to the fact that most of the participants in this study are interested in their ethnic background and cultural heritage or have parents who are active in Hungarian societies. ${ }^{8}$

The fourth research question introduces the comparative aspect, observing similarities and differences between the Swedish-Hungarians' and the Finnish-Hungarians' language choices, looking for possible causes. Despite of the small sample size $(\mathrm{N}=88)$, it can be generally stated that the language patterns in both groups are similar, though the FinnishHungarians tend to have better language skills due to the fact that they used Hungarian during their childhood to a greater extent than the Swedish-Hungarians. Therefore the Finnish-Hungarians use Hungarian more often in their daily lives than their Swedish counterparts today. Regarding the informants' relationships to the Hungarian language, the Finnish-Hungarians have a more positive and open view than the Swedish-Hungarians. When it comes to having an interest for Hungary and the Hungarian culture, it is again the Finnish-Hungarians who are more positive than the Swedish-Hungarians. The Hungarian identity is also more present among Finnish-Hungarians than Swedish-Hungarians.

The results of the survey show that the continuation of the language and culture are highly dependent on what happens at the grass-roots level within the family. However, there may be other circumstances that can be said to have an important role in the preservation of a language. An example of this could be the situation for the Finnish-Hungarians who are met with positive attitudes from the society around them and even receive support at the national level that helps to maintain and sustain the language and culture. The parents' immigration background possibly plays a role as well: the mainly non-refugee status among the Finnish-Hungarians might have positive effect. The positive results regarding Finnish-Hungarians can also be related to a time aspect; Finnish-Hungarians came to Finland later and the second generation members are younger on average than the Swedish-Hungarians. Prior to the 1980s, there was not a general understanding in society about the benefits of bilingualism, multilingualism and cultural diversity, and immigrants were not encouraged to retain their minority language skills or their cultural heritage. There has also been a political development in Hungary beginning at the end of the 1980s and continuing through the early 1990s which has had a positive impact on Hungarians abroad, allowing them to preserve their language and their culture. (See e.g. Pomogáts 1997; Fenyvesi 2005; Straszer 2011a, 27-30.) It is noteworthy that SwedishHungarians are more organized than Finnish-Hungarians and that they are one of the most active groups of Hungarians abroad. But this alone does not give sufficient support to preserve the Hungarian language and culture for future generations.

\footnotetext{
${ }^{8}$ Discussion in detail about materials and methods with source criticism are presented in Straszer 2011a, $75-92$.
} 


\section{Conclusion}

Regarding Hungarians and the status of the Hungarian language in Swedish and Finnish societies, there is a strong common denominator for those persons of Hungarian descent permanently residing in Sweden and those in Finland, that is their Hungarian roots, the Hungarian language and that both of these groups live as a minority immigrant people group in a northern European society. But it is evident that Hungarians are not one unified group in Sweden and Finland in part because both of these Hungarian groups have different sociocultural situations dependent upon the time and reason for the immigration. Other factors playing a role in the situation of Hungarians today are geographical dispersion throughout the country, culture-historical and societal reasons, as well as individual differences with regards to the Hungarian culture in the mother country and religious beliefs.

Table 3 (from Straszer 2010a, 82-83) summarizes characteristic similarities between these two groups. It provides an overview of and reasons for the distinctions between the sociocultural positions of the Hungarian people and the Hungarian language in these two different societies.

Table 3. Similarities and differences between Finnish- and Swedish- Hungarians' sociocultural position in society.

\section{Finnish-Hungarians}

Immigrants from "our Finno-Ugric family", represents a brother nation

$\rightarrow$ can be seen as having a high status in society

Most immigrants arrived during the 1970's and 1980's

$\rightarrow$ warm reception due to the fact that many were recruited to join the labour market

The majority of immigrants are highly education and come because they are experts within certain fields and have been recruited as labourers or they have moved because of family reasons.

$\rightarrow$ the move to Finland was often a conscious and well-planned decision

Relatively small immigrant population spread throughout the entire country

$\rightarrow$ fewer opportunities to maintain contact with other Hungarians, to arrange Hungarian activities or establish Hungarian media

Relatively small group with large geographic spread, as well as a new tradition of offering mother tongue education for students with immigrant background

$\rightarrow$ fewer opportunities to receive mother tongue education in Hungarian, yet due to cultural and historical reasons there are other opportunities for studying the Hungarian language

\section{Swedish-Hungarians}

Immigrants from Eastern-Europe, from several formerly communist countries

$\rightarrow$ can be seen as having a low status in society

Most immigrants arrived during the 1950's and 1960's

$\rightarrow$ warm reception due to the open assimilatory immigrant politics that were the norm at that time

The majority of immigrants are political or economical refugees from all classes in society with various levels of education

$\rightarrow$ the move to Sweden was often the result of chance determined by temporary coincidences

Relatively large groups on immigrants live in a handful of "centers" throughout Sweden

$\rightarrow$ more opportunities to maintain contact with other Hungarians, to arrange Hungarian activities and establish Hungarian media

Relatively large group with high concentration in certain areas, as well as a long tradition of offering mother tongue education for students with immigrant background

$\rightarrow$ more opportunities to receive mother tongue education in Hungarian, yet few other opportunities for studying the Hungarian language 
The survey shows interesting results concerning differences between the SwedishHungarians' and the Finnish-Hungarians' language choice and identity. As was mentioned above, Hungarians in Finland have more advanced language skills in Hungarian, are more interested in Hungary and Hungarian culture and have a more positive and open view to their Hungarian heritage and have a more present Hungarian identity compared to Hungarians in Sweden. This article presented the main features of Hungarian immigration and some macro and micro level factors which can influence the Hungarians linguistic situation in two neighbouring Nordic countries. The overview in table 3 shows that Swedish-Hungarians and Finnish-Hungarians to some extent have different conditions that enable them to keep the Hungarian language and culture alive. Swedish-Hungarian groups are able to meet regularly in certain areas, due to the size of the Hungarian population and concentration in these areas, and together they help to maintain the Hungarian culture. While Finnish-Hungarians, even though they make up a smaller minority with a more diverse spread throughout the country, are able to maintain the Hungarian identity and language because they are seen as having a higher status and they are met by positivity from the majority of the population. In both groups there are underlying factors that work either for or against those conditions that lead to the preservation of the minority language and culture. But as the survey shows it seems to be evident that the status of Hungarians in the society and some factors on the family and individual level account for the differences in the language choice and identity of the Hungarians in the two countries.

\section{References}

Abonyi-Karhunen, Adrienn. 2005. A Finnország-sztereotípiák változása az útikönyvekben. In: Hungarologische Beiträge 17, edited by Ágnes Pasztercsák, pp. 5-34. Universität Jyväskylä.

Borbándi, Gyula. 1996. Emigráció és Magyarország. Nyugati magyarok a változások éveiben 1985-1995. Európai Protestáns Magyar Szabadegyetem. Basel-Budapest.

Boyd, Sally. 1985. Language survival: A study of language contact, language shift and language choice in Sweden. Dissertation. Department of Linguistics, University of Gothenburg. Gothenburg Monographs in Linguistics 6. Göteborg.

Boyd, Sally, Anne Holmen and Normann Jens Jørgensen. 1994a. (eds.) Sprogbrug og sprogvalg blandt indvandrere i Norden. Pohjoismaihin muuttaneiden kielen valinta ja käyttö. Bind 1. Gruppebeskrivelser. Københavnerstudier i tosprogethed bind 22. København.

Boyd, Sally, Anne Holmen and Normann Jens Jørgensen. 1994b. (eds.) Sprogbrug og sprogvalg blandt indvandrere i Norden. Pohjoismaihin muuttaneiden kielen valinta ja käyttö. Bind 2. Temaartikler. Københavnerstudier i tosprogethed bind 22. København.

Bæhrendtz, Nils Erik. 1957. Vi såg det hända. En bok om den ungerska folkresningen. Rabén och Sjögren. Stockholm. 
Fenyvesi, Anna. 2005. (Ed.) Hungarian Language Contact Outside Hungary. Studies on Hungarian as a minority language. Amsterdam and Philadelphia.

FSBS (The Finnish State Bureau of Statistics). 2012. The official statistics of The Finnish State Bureau of Statistics. Available from: http://tilastokeskus.fi/meta/svt/index en.html

Gerevich-Kopteff, Éva. 1993. Magyarságőrzés és beilleszkedés Finnországban. In: Régi és új peregrináció. Magyarok külföldön, külföldiek Magyarországon. Peregrination, Old and New. Hungarians Abroad and Foreigners in Hungary, edited by Imre Békési, József Jankovics, László Kósa, and Judit Nyerges, pp. 1274-1279. III. Magyar nyelvészek külföldön - külföldiek Magyarországon. Hungarian Linguists Abroad, Foreign Linguists in Hungary. Nemzetközi Magyarságtudományi Társaság - Scriptum Kft. Budapest-Szeged.

Hellman, Lisa. 2004. Attityder till språk. En undersökning av attityder till svenska och till avvikande svenska i Sydnärke. Humanistiska institutionen, Svenska språket. Örebro universitet.

György-Ullholm, Kamilla. 2010. Same Mother Tongue-Different Origins. Implications for Language Maintenance and Shift among Hungarian Immigrants and their Children in Sweden. Dissertations in Bilingualism 20. Centre for Research on Bilingualism. Stockholm University. Stockholm.

Honka-Hallila, Helena. (Ed.) 2000. Meidän Unkari. Suomi-Unkari Seura 1950-2000. Suomi-Unkari Seura. Gummerus.

HTMH (Határon Túli Magyarok Hivatala). 2006. 2005-ös jelentés a Kárpát-medencén kívül élő magyarság helyzetéről. Határon Túli Magyarok Hivatala . Available from: <http://www.hhrf.org/htmh/printable version.php $>$ (2006.01.13).

Iskanius, Sanna. 2006. Venäjänkielisten maahanmuuttajaopiskelijoiden kieliidentiteetti. Jyväskylä Studies in Humanities 51. Jyväskylä.

Jaakkola, Magdalena. 2000. Asenneilmasto Suomessa vuosina 1987-1999. In: Monikulttuurinen Suomi. Etniset suhteet tutkimuksen valossa, edited by Karmela Liebkind, pp. 28-55. Gaudeamus. Helsinki.

- 2005: Suomalaisten suhtautuminen maahanmuuttajiin vuosina 1987-2003. Työpoliittinen tutkimus 286. Työministeriö. Helsinki.

Janulf, Pirjo. 1998. Kommer finskan i Sverige att fortleva? En studie av språkkunskaper och språkanvändning hos andragenerationens sverigefinnar $i$ Botkyrka och hos finlandssvenskar $i$ Abo. Acta Universitatis Stockholmiensis. Studia Fennica Stockholmiensia 7. Stockholm.

Jasinskaja-Lahti, Inga and Karmela Liebkind. 1999a. Venäjänkielisten maahanmuuttajanuorten perhearvot ja identiteetti. In: Monikulttuurinen Suomi. Etniset suhteet tutkimuksen valossa, edited by Karmela Liebkind, pp. 124-137. Helsinki.

Jasinskaja-Lahti, Inga and Karmela Liebkind. 1999b. Exploration of the Ethnic Identity of Russian-Speaking Immigrant Adolescents in Finland. In: Journal of Cross-Cultural Psychology, 30(4): 527-539.

Kodolányi, János. 1939. Suomi titka. Magyar Élet. Budapest.

Korhonen, Mikko. 1984. Suomalais-ugrilaisen kielitieteen alkuvaiheet. In: Ystävät sukulaiset. Suomen ja Unkarin kulttuurisuhteet 1840-1984, edited by János Nagy, Endre Gombár, Péter Hajdú jr., János Kodolányi, Imre Lázár, József Oláh, and 
Sándor Petróczi, pp. 25-45. Suomalaisen Kirjallisuuden Seuran Toimituksia 403. Helsinki.

Kós-Dienes, Dora. 1986. Semantisk analys av tidningsartiklar om ungerska flyktingar. In: Modeller för positiva kulturmöten, edited by Christina Stendahl, pp. 65-88. Papers in anthropologica linguistics, 15. Göteborg.

Kosonen, Liisa. 1994. Vietnamilainen oppilas kahden kulttuurin välissä. In: Maahanmuuttajat. Kulttuurien kohtaaminen Suomessa, edited by Karmela Liebkind, pp. 192-223. Helsingfors.

Kostoulas-Makrakis, Nelly. 1995. Language Maintenance or Shift? A study of Greek background students in Sweden. Studies in comparative and international education 33. Stockholm.

Kovács, Andor. 1999. A világ magyarsága. Európa I. Magyarok Világszövetsége Nyugati Régiója. Budapest.

Kovács, Magdolna 2011. Ethnic and linguistic identities of Hungarians and their descendants in Finland. In: Ethnic and Linguistic Context of Identity: Finno-Ugric Minorities, edited by Riho Grünthal and Magdolna Kovács, pp. 121-159. Uralica Helsingiensia 5. Helsinki.

Kärkkäinen, Tanja and Kaarina Mononen. 1999. Maahanmuuttajavanhukset ja suomen kieli: haastattelututkimus inkerinsuomalaisten, bosnialaisten ja vietnamilaisten vanhusten kielenoppimismotivaatiosta, sosiaalisista verkoista ja etnolingvistisestä identiteetistä. Vanhustyön keskusliitto. Ituja vanhustyöhön. Helsinki.

Leitzinger, Antero. 2008. Ulkomaalaispolitiikka Suomessa 1812-1972. Helsinki: East-West Books. Helsinki.

Lepola, Outi. 2000. Ulkomaalaisesta suomenmaalaiseksi. Monikulttuurisuus, kansalaisuus ja suomalaisuus 1990-luvun maahanmuuttopoliittisessa keskustelussa. Suomalaisen Kirjallisuuden Seuran Toimituksia 787. Suomalaisen kirjallisuuden seura. Helsinki.

Liebkind, Karmela. 1994. Maahanmuuttajat ja kulttuurien kohtaaminen. In: Maahanmuuttajat. Kulttuurien kohtaaminen Suomessa, edited by Karmela Liebkind, pp. 21-49. Helsinki.

Lithman, Yngve. (ed.) 1987. Nybyggarna i Sverige. Invandring och andragenartion. Minervaserien. Stockholm.

Lundquist, Agne and Karin Busch. 1966. Främling i Sverige. Om ungerska flyktingars anpassning. Argos Förlags AB. Uppsala.

MV (Magyarok Világszövetsége). 1996. Magyarok Világszövetsége a nemzet szolgálatában. World Federation of Hungarians. Második javított kiadás. MVSZ Hivatala. Budapest.

Nagy, János. 1984. Esipuhe. In: Ystävät sukulaiset. Suomen ja Unkarin kulttuurisuhteet 1840-1984, edited by János Nagy, Endre Gombár, Péter Hajdú jr., János Kodolányi, Imre Lázár, József Oláh, and Sándor Petróczi, pp. 10-15. Suomalaisen Kirjallisuuden Seuran Toimituksia 403. Helsinki.

Nagy, János, Endre Gombár, Péter Hajdú jr., János Kodolányi, Imre Lázár, József Oláh, and Sándor Petróczi (eds.). 1984. Ystävät sukulaiset. Suomen ja Unkarin kulttuurisuhteet 1840-1984. Suomalaisen Kirjallisuuden Seuran Toimituksia 403. Helsinki.

Namei, Shidrokh. 1993. Tvåspråkiga elever i grundskolan. In: Språk och miljö $i$ 
Botkyrka. Rapport från den språkvetenskapliga pilotundersökningen, edited by Åke Viberg, Veli Tuomela and Namei Shidrokh, pp. 39-94. Rapporter om tvåspråkighet 8. Centrum för tvåspråkighetsforskning. Stockholm.

Nygård, Pia. 2002. Språkattityder i Sverige. Bilaga till Mål i mun. Förslag till handlingsprogram för svenska språket. SOU 2002:27.

Oinonen, Liisa. 1999. Vietnamilaisia, suomalaisia vai suomenvietnamilaisia? Pääkaupunkiseudun vietnamilaisten etnisyys ja identiteetti 1990-luvulla. Väestöntutkimuslaitos. Katsauksia E6. Helsinki.

Olkiewicz, Eva. 1990. Invandrarfamiljer i förändring: En studie över finska och jugoslaviska invandrarungdomar och deras föräldrar. Studies in Comparative and International Education No 17. Stockholm.

Otterup, Tore. 2005. "Jag känner mej begåvad bara". Om flerspråkighet och identitetsskonstruktion $i$ ett multietniskt förortsområde. Institutionen för svenska språket. Göteborg.

Pomogáts, Béla. 1997. Nyelvújítás az ezredfordulón. - Nyelvünk és Kultúránk 98. pp. 95-100.

Puskás, Tünde. 2009. "We Belong to Them”. Narratives of Belonging, Homeland and Nationhood in Territorial and Non-territorial Minority Settings. Linköpings Studies in Arts and Science No. 445. Multiple Europes No. 43. Bruxelles.

Richly, Gábor. 1996. Unkari ja Suomen talvisota. Sotahistoriallinen aikakauskirja. Sotahistoriallisen Seuran ja Sotamuseon julkaisuja. 15: 134-196.

SCB (Statistiska centralbyrån). 1987. Folkmängd 31 dec 1986 enligt indelningen 1 jan 1987. Del 3. Fördelning efter kön, ålder, civilstånd och medborgarskap i kommuner $\mathrm{mm}$. Sveriges officiella statistik. Statistiska centralbyrån. Stockholm.

- 2006. Tabeller över Sveriges befolkning 2005. Befolkningsstatistik. Sveriges officiella statistik. Statistiska centralbyrån. Örebro.

- 2010. Tabeller över Sveriges befolkning 2009. Befolkningsstatistik. Sveriges officiella statistik. Statistiska centralbyrån. Örebro.

Sirén, Ulla 1991. Minority Language Transmission in Early Childhood. Parental intention and language use. Studies in Comparative and International Education 21. Stockholm.

SMOSZ (Svédországi Magyarok Országos Szövetsége) 2008. Ungerska Riksförbundets hemsida, Svédországi Magyarok Országos Szövetsége. Available from: $<$ http:// www.smosz.org/sindex.htm $>$ (2008.02.20). SOU 2002. Mål i mun - Förslag till handlingsprogram för svenska språket. Statens offentliga utredningar 2002: 27. Kulturdepartementet. Slutbetänkande av Kommittén för svenska språket Stockholm.

Straszer, Boglárka. 2006a. Femtio år i Sverige. Invandrare och minoriteter 5/2006: $9-12$.

- 2006b. Ungrare - en osynlig men aktiv invandrargrupp i Norden. In: Humanister forskar. Humanistdagarna vid Uppsala universitet 2006, edited by Gunilla Ransbo, pp. 211-217. Uppsala

- 2009. Unkarilaiset Suomessa. Siirtolaisuus - Migration 1/2009: 12-21. Turku: Institute of Migration 
- 2010a. Ungrare, ungerska och ungersk kultur i Sverige och Finland. En översikt. (Digitala skrifter från Hugo Valentin-centrum 1.) Uppsala universitet. Uppsala. Available from: http://urn.kb.se/resolve?urn=urn:nbn:se:uu:diva-133236. (2012.12.14).

- 2010b. "Unkarilaisuus tekee minusta persoonallisen" - Pohdintoja toisen polven suomenunkarilaisten kieli-identiteetistä. In: Maahanmuntto ja sukupolvet, edited by Tuomas Martikainen and Lotta Haikkola, pp. 193-216. Tietolipas 233. Nuorisotutkimusverkoston julkaisuja 106. Helsinki.

— 2011a. "Ungerska för rötternas skull". Språkval och identitet bland andragenerationens ungrare i Sverige och Finland. Acta Universitatis Upsaliensis. Studia Uralica Upsaliensia 38. Uppsala.

- 2011b. Embracing Hungarian: top-down emancipation of an immigrant language in Finland. In: The Many Faces of Language Emancipation, edited by Leena Huss and J. Shaun Nolan. Special Issue. International Journal of Sociology of Language, 209 , pp. 75-90.

- 2011c. Language and Identity among Hungarians in Sweden. In: Ethnic and Linguistic Context of Identity: Finno-Ugric Minorities, edited by Riho Grünthal and Magdolna Kovács, pp. 161-195. Uralica Helsingiensia. 5. Helsinki.

Svanberg, Ingvar and Mattias Tydén. 1992. Tusen år av invandring. En svensk kulturhistoria. Gidlunds Bokförlag, Stockholm.

Svensson, Anders. 1992. Ungrare i folkhemmet, Svensk flyktingpolitik i kalla krigets skugga. Cesic Studies in International Conflict 7. Lund University Press. Studentlitteratur. Lund.

Szabó, Mátyás. 1988. Ungrare. In: Det mångkulturella Sverige. En handbok om etniska grupper och minoriteter, edited by Ingvar Svanberg and Harald Runblom, pp. 463-471. Centrum för multietnisk forskning vid Uppsala universitet. Gidlunds Bokförlag Stockholm.

- 1997. Vägen mot medborgarskap. Studier i medborgarskapsbyte och integration. Bokförlaget Arena.

Szíj, Enikő. 1989. Suomalais-ugrilainen heimoaate. In: Helsingin yliopiston unkarilainen laitos 60-vuotias, edited by Márta Csepregi, pp. 76-83. Folia Hungarica 3. Castrenianumin toimitteita 33. Helsinki.

Szöllősi, Antal. 1999. Svédországi magyarság 1956-ig. Ungerska Arkivet. Stockholm.

Tervonen, Viljo. 1984. Kulttuurisuhteiden rakentajia 1800-luvulla. In: Ystävät sukulaiset. Suomen ja Unkarin kulttuurisuhteet 1840-1984, edited by János Nagy, Endre Gombár, Péter Hajdú jr., János Kodolányi, Imre Lázár, József Oláh, and Sándor Petróczi, pp. 46-87. Suomalaisen Kirjallisuuden Seuran Toimituksia 403. Helsinki.

Varpio, Yrjö and Lajos Szopori Nagy. 1990. Suomen ja Unkarin kirjalliset suhteet vuosina 1920-1986. Suomalaisen Kirjallisuuden Seura, Suomi 153. Helsinki.

Weckström, Lotta Linnea. 2008. Representations of Finnishness in Sweden. Väitöskirja. Soveltavan kielentutkimuksen keskus. Humanistinen tiedekunta, Jyväskylän yliopisto. Jyväskylä. 
Wingstedt, Maria. 1998. Language Ideologies and Minority Language Policies in Sweden. Historical and contemporary perspectives. Centre for Research on Bilingualism. Stockholm University. Centrum för tvåspråkighetsforskning. Stockholms universitet.

Zsiga, Erik. 2007. Hejdå Östeuropa! Timbro. Stockholm.

Ågren, Marja. 2006. "Är du finsk, eller ...” En etnologisk studie om att växa upp och leva med finsk bakgrund $i$ Sverige. Skrifter från Etnologiska föreningen i Västsverige. Göteborg.

Österlund-Pötzsch, Suzanne. 2003. American Plus. Etnisk identitet hos finlandssvenska ättlingar i Nord-Amerika. Skrifter utgivna av Svenska Litteratursällskapet i Finland, $\mathrm{nr} 658$. Helsingfors. 